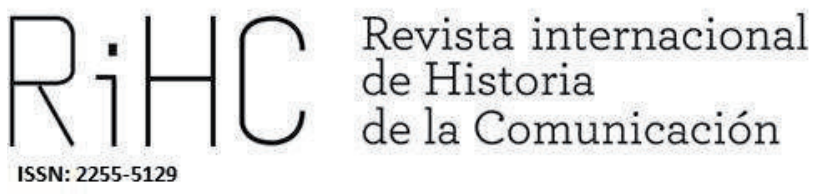

\title{
FEMINISMO, PODER E REPRESENTAÇÕES MEDIÁTICAS AO LONGO DOS 40 ANOS DA DEMOCRACIA PORTUGUESA
}

Feminism, power and media representations over the initial $\mathbf{4 0}$ years of Portuguese Democracy

DOI: http://dx.doi.org/10.12795/RiCH.2021.i16.09

Recibido: 23-4-2021

Aceptado: $13-5-2021$

Publicado: 30-5-2021

\begin{abstract}
Ana Cabrera
Universidade Nova de Lisboa, Instituto de História Contemporânea, Portugal anacabrera@fcsh.unl.pt ORCID (i) http://orcid.org/0000-0002-2372-5165
\end{abstract}


Resumo: Em Portugal, o período pós-revolucionário, não originou alterações nas questões da igualdade entre homens e mulheres. Contudo, nos últimos 40 anos, houve duas questões centrais para a igualdade de género, debatidas no Parlamento: a paridade e a legalização do aborto. Em 1975 a política era profundamente masculina e os homens ocupavam o centro das decisões em todas as esferas da sociedade. Quarenta anos depois, a representação das mulheres na Assembleia da República passou 7,6\% para 40\% em 2019, graças à aprovação da Lei da Paridade em 2006.

Também a luta pela despenalização do aborto se arrastou desde 1974 a 2007, altura em o segundo referendo foi aprovado. Este consistiu num processo longo e muito polarizado, com confronto de posições antagónicas, dentro e fora do Parlamento. Neste percurso intervieram, partidos políticos, ONGs e diversas organizações de mulheres.

Neste artigo analisaremos as dinâmicas sociais e políticas que propiciaram aquelas mudanças, destacaremos as lutas em que as mulheres se envolveram, e examinaremos as alterações na cobertura mediática para as questões de género, a partir de dois casos centrais: a Paridade e a Interrupção Voluntária da Gravidez (IVG). Verificamos que foram os debates sobre estes assuntos que mais envolveram as mulheres, e que mais contribuíram para a tomada de consciência da sua situação face à sociedade patriarcal, abrindo portas à sua emancipação e empoderamento.

Palavras-Chave: Igualdade de Género, Paridade Política, Interrupção Voluntária da Gravidez (IVG), Cobertura Jornalística

Resumen: En Portugal, el período posrevolucionario no cedió lugar a cambios en las cuestiones de igualdad entre hombres y mujeres. Sin embargo, en los últimos 40 años, ha habido dos temas centrales para la igualdad de género, discutidos en el Parlamento: la paridad y la legalización del aborto. En 1975, la política era profundamente masculina y los hombres estaban en el centro de las decisiones en todas las esferas de la sociedad. Cuarenta años después, la representación de las mujeres en la Asamblea de la República pasó del 7,6\% al 40\% en 2019, gracias a la aprobación de la ley de paridad en 2006.

La lucha por la despenalización del aborto también se prolongó desde 1974 hasta 2007, cuando se aprobó el segundo referéndum. Este ha consistido en un proceso largo y muy polarizado, con enfrentamiento de posiciones contrarias, dentro y fuera del Parlamento. En este recorrido intervinieron partidos políticos, ONG y diversas organizaciones de mujeres.

En este artículo analizaremos las dinámicas sociales y políticas que llevaron a estos cambios, resaltaremos las luchas en las que participaron las mujeres y examinaremos los cambios en la cobertura mediática de la problemática de género, a partir de dos casos centrales: la paridad y la interrupción voluntaria del embarazo (IVG). Concluimos que fueron los debates sobre estos temas los que más involucraron a las mujeres, y que más contribuyeron a la toma de conciencia de su situación frente a la sociedad patriarcal, abriendo puertas a su emancipación y empoderamiento.

Palabras clave: igualdad de género, paridad política, interrupción voluntaria del embarazo (IVG), cobertura de noticias.

\footnotetext{
Abstract: The democratic revolution process in Portugal (1974-1976) did not result in immediate changes on gender equality. Yet, over the past four decades there were two main gender equality achievements in Portugal following parliamentary debate: the gender parity law and the legalisation of abortion. In 1975, Portuguese politics was profoundly dominated by men, who occupied the decision-making posts across all
} 
instances and sector of society. But since then, women representation in parliament jumped from $7.6 \%$ in 1976 to $40 \%$ in 2019, as a result of the gender parity law enacted in 2006. The debate about the legalisation of abortion was polarised and lengthy. It lasted between 1974 and 2007, it involved political parties, NGOs, several women's organisations, and two referenda, the last one in 2007, which settled the issue. In this paper we assess the social and political dynamics that enabled these changes, highlighting the involvement of women. We examine the changes in media coverage on gender issues, using these two central cases for gender equality in Portugal: the gender parity law and the legalisation of abortion. We found that these were the social and political debates that most involved the participation of women. These debates revealed the condition of women in a patriarchal society, and led to their emancipation and empowerment.

Keywords: gender equality, gender parity, legalisation of abortion, media coverage

\section{Introdução e Metodologia}

Em Portugal a revolução de Abril não trouxe visibilidade mediática às mulheres. Esta revolução foi um processo de grande complexidade onde, simultaneamente, se colocava o fim do Estado Novo, a construção da democracia e o fim da guerra colonial. Nesta altura, as prioridades eram as lutas políticas pela democracia e, por isso, a questão da igualdade entre homens e mulheres era secundária. O que na realidade contava era o "processo revolucionário em curso" e a "aliança entre o povo e o MFA". Ainda assim, houve na situação das mulheres alterações que cortaram com a herança do salazarismo, como foi o caso do acesso à carreira diplomática, à magistratura, o direito ao voto, a aprovação da lei do divórcio e a recuperação de direitos civis negados pelo Estado Novo.

Todavia, em 1976, a política era profundamente masculina y os homens ocupavam o centro das decisões. Apesar do epiteto de progressista, associado à Constituição, aprovada em 1976, todo o processo legislativo "é eminentemente marcado por um paradigma patriarcal razão pela qual a lei, baseada numa hierarquia de género, tende a negligenciar diversos tipos de violência exercidos sobre as mulheres" (Duarte e Barradas, 2008: 79). Esta situação explica, segundo os autores, que apesar das leis observarem a igualdade formal entre homens e mulheres, persistem em penalizar a interrupção voluntária da gravidez. Barreiras semelhantes são as que se interpõe no debate da paridade na política, embora, neste caso, se esbarre em questões de ordem ideológica, onde a ponderação entre o mérito e as medidas de ação positiva, se colocavam.

Os meios de comunicação acompanharam a sociedade e, também eles, permeáveis à questão das liberdades, estavam integrados numa sociedade profundamente patriarcal. Por isso, os media raramente escolhiam mulheres para as suas fotos e, quando o faziam representavam estereótipos - mulheres velhas, rurais, pobres, vestidas de negro e 
lenços na cabeça (Ross e Comrie, 2012; Silveirinha, 2006; Silveirinha e Peixinho, 2008; Norris, e Lovenduski, 1989).

Durante muito tempo, a cobertura jornalística sobre questões de género baseava-se sobretudo em pseudo-acontecimentos, como o Dia Internacional das Mulheres e outras efemérides (Cerqueira, 2012). Por outro lado, o jornalismo repercute o sistema de poder dentro das bancadas parlamentares, onde as mulheres são excluídas. Os próprios valores-notícia de que os jornalistas se servem nas suas práticas profissionais mimetizam as práticas e as figuras do poder (Baptista, 2017: 160)

A mudança no jornalismo será lenta e virá mais tarde, à medida que os debates sobre as questões de igualdade de género penetram na sociedade e entram na discussão política. Um aspeto que merece reflexão sobre os efeitos na cobertura jornalística de assuntos sobre mulheres, é a feminização das redações ao longo dos anos 90, e durante as primeiras décadas do novo milénio. A este propósito Balanza (2004: 149) adverte que a imprensa necessita de modificar as suas mensagens para diversificar e incrementar as suas audiências: como já tem ocorrido ao aplicar as novas tecnologias dos meios de comunicação, mas a solução perece estar na segmentação dos mercados. "A audiência feminina agradeceria uma recondução das mensagens, oferecendo mais relevância a determinadas temáticas, possibilitando opiniões plurais, introduzindo mulheres como personagens de referência, com a finalidade de incrementar as fontes de informação ativando o processo comunicativo tendo em vista uma sociedade mais equitativa".

Só quarenta anos mais tarde (2006) a situação das mulheres na política sofreu alterações visíveis. A representação das mulheres no parlamento passou 5,7\% em 1976, para 38,7\% em 2019. Já no executivo a presença feminina passou a ser de $36,1 \%$, o décimo melhor registo da UE segundo o Eurostat. (Cabrera et al., 2016 e Cabrera e Martins, 2019). Contudo, um outro aspeto fundamental, sobre os direitos das mulheres, teve também um longo caminho no debate parlamentar: foi a despenalização do aborto e mais tarde a aprovação da Interrupção Voluntária da Gravidez (IVG) em 2007. O debate ocupou várias legislaturas, dois referendos e estendeu-se ao longo de 25 anos. De facto, as grandes questões da igualdade de género no debate parlamentar, que proporcionaram movimentações cívicas das mulheres, em particular, e da sociedade em geral, foram a aprovação da Lei da Paridade e a aprovação da IVG. Estas decisões mudaram e marcaram a vida das mulheres portuguesas, contribuíram para a construção das mulheres como sujeito político, e mudaram também as formas de funcionamento dos partidos políticos (Baum, e Espírito-Santo, 2012).

Neste artigo, o nosso objetivo é compreender as dinâmicas que proporcionaram a aprovação da Lei da Paridade em 2006 e da lei da IVG em 2007; conhecer as lutas em que as mulheres portuguesas se envolveram, as suas formas de organização, as conquistas alcançadas e, paralelemente, analisar o papel dos meios de comunicação em todo este processo. 
Este assunto interpela diversas interrogações: Que contextos e dinâmicas propiciaram a aprovação das leis da paridade e da interrupção da gravidez? Que lutas foram travadas para a concretização daqueles objetivos? Quem foram as /os protagonistas? Que papel desempenharam os media?

Partimos de uma análise em profundidade da literatura produzida sobre o tema mulheres na política, da evolução da participação das mulheres no parlamento português e europeu, a ação das organizações internacionais como a Organização das Nações Unidas (ONU), os grandes encontros internacionais de mulheres, da relevante ação da União Europeia (UE) e das suas organizações que trabalham em prol da igualdade de género.

Nesta investigação a metodologia combina a perspetiva histórica de análise documental e crítica, com uma análise quantitativa das deputadas portuguesas na Assembleia da República e no Parlamento Europeu. Tivemos também em consideração análise dos contextos que foram os cenários destes acontecimentos, descrevendo-os e interpretando-os à luz das limitações das diferentes conjunturas. O processo de conhecimento foi enriquecido com o recurso a fontes documentais como os materiais constantes do Arquivo do Parlamento da Assembleia da República, os dados sobre a composição do Parlamento Europeu (documentação que existe online), Documentação do Arquivo da Comissão para a Igualdade de Género (CIG) e da Casa Comum (Fundação Mário Soares). Os jornais que selecionámos para avaliar a evolução da cobertura das mulheres na política foram, essencialmente, o semanário Expresso, o Diário de Notícias e o Público e o Independente e o seu uso, neste trabalho, será esporádico e tido como forma de sublinhar os períodos mais polémicos dos dois processos legislativos considerados neste trabalho: a IVG e a Lei da Paridade.

\section{Igualdade na representação política - Paridade}

O 25 de Abril trouxe grandes mudanças na política portuguesa, a vivencia democrática como forma de estimular a cidadania, para as questões da igualdade entre homens e mulheres. As primeiras medidas, consistiram na correção de grandes injustiças, praticadas pelo Estado Novo: abertura às mulheres portugueses de carreiras profissionais que antes thes estavam vedadas, como a diplomacia, a magistratura e a administração local; para além da recuperação de direitos civis, como o direito ao voto, ao divórcio, a liberdade de deslocação ao estrangeiro, sem a tutela de maridos ou pais. 
$\mathrm{Na}$ Assembleia Constituinte de 1975-76, foram eleitas 20 mulheres entre 230 homens. E no debate da Constituição as mulheres não são destacadas como portadoras de défice de direitos. São assim incluídas na expressão do Artigo 13 da Constituição Portuguesa:

1. Todos os cidadãos têm a mesma dignidade social e são iguais perante a lei. 2. Ninguém pode ser privilegiado, beneficiado, prejudicado, privado de qualquer direito ou isento de qualquer dever em razão de ascendência, sexo, raça, língua, território de origem, religião, conviçcões políticas ou ideológicas, instrução, situação económica, condição social ou orientação sexual.

O défice de participação feminina na política, na cidadania e sociedade, está patente neste articulado constitucional, porque ignora que cidadãos são homens e mulheres, numa sociedade que é constituída por homens e mulheres. Naquela altura, a Comissão da Condição Feminina ${ }^{1}$ contestou a formulação constitucional e salientou que "queremos uma sociedade pensada por homens e mulheres, em que as mulheres possam ser genuinamente elas, e não mulheres ao gosto dos homens, ou contra o gosto dos homens, tal coisa deve ser tornada clara e afirmada sem equívocos" (Boletim da Comissão da Condição Feminina, março de 1976: 5).

A adesão de Portugal à Comunidade Europeia (CE) em 1986 contribuiu com um forte impulso nas questões da condição das mulheres. A aprovação do "Programa Comunitário a Médio Prazo para a Igualdade de Oportunidades para as Mulheres (19861990)", embora tímido, salvaguardava a igualdade em áreas como educação, emprego e formação profissional, segurança social, as novas tecnologias, partilha de responsabilidades familiares e mudança de atitudes relativamente aos papéis dos homens e das mulheres na sociedade portuguesa. As questões das medidas de ação positiva, em relação à participação na política, não eram ainda consideradas. Pela mesma altura, o Conselho da Europa, no seu programa a médio prazo (1987-1991), acrescentava que as questões sobre o défice de participação das mulheres, deviam ser resolvidas a partir de propostas de caráter jurídico, sensibilização dos media, e estímulo à participação na vida política.

Contudo, os anos 90, foram sem dúvida, testemunhos de ponderação sobre as alterações acerca das questões sobre as mulheres e sobre a igualdade, como bem sublinha Regina Tavares da Silva (2010).

Foi nesta década que se verificou uma movimentação nas grandes instituições internacionais, nomeadamente, a ONU, a UE e o Conselho da Europa. Estas instituições

\footnotetext{
${ }^{1}$ A Comissão da Condição Feminina foi criada em 1970. É uma organização governamental. Depois do 25 de Abril desenvolveu uma dinâmica no sentido de alertar para a situação feminina no que respeita às questões das desigualdades. Esta Comissão passa a partir de 1991 a ser designada por Comissão para a Igualdade e para os Direitos das Mulheres (CIDM); a partir de Maio de 2007 para a ser designada por Comissão para a Cidadania e Igualdade de Género (CIG)
} 
foram fundamentais para alavancar a situação das mulheres, para colocar na ordem do dia a igualdade de género e promover, através de um longo caminho, a influência dos diversos países do mundo a adotar medidas de ação positiva e promover o empoderamento das mulheres.

A 4a Conferência Mundial sobre a Mulher que teve lugar em Pequim, em 1995, constituiu um momento de viragem simbólica na luta das mulheres. Para trás ficaram diversos outros encontros mundiais desde o México em 1975, que progressivamente criaram as condições propicias à aprovação da Plataforma de ação de Pequim que é, simultaneamente, um programa de ação, um compromisso político, onde os direitos das mulheres e a igualdade de género são, a partir de então, encarados segundo a orientação da promoção dos direitos humanos fundamentais (Silva, 2010)

A igualdade de género e o empoderamento da mulher foram fundamentais para que, segundo aquela autora, se tenham tornado centrais na política; estabeleceu-se um quadro normativo, quase consensual, entre os países, e, tanto ao nível institucional, como a nível programático, foram promovidas medidas de igualdade de género, bem como a difusão do seu conhecimento.

No quadro da UE, os Tratados que mais contribuíram para a igualdade de género e o empoderamento da mulher foram, sem dúvida, o Tratado de Amesterdão (1997). Este tratado, reforça o empenhamento europeu na igualdade de géneros e foi, particularmente importante, em relação à igualdade entre homens e mulheres, no plano laboral, em toda a UE. Por exemplo, o Artigo 20 do Tratado da Comunidade Europeia proclama a igualdade entre homens e mulheres, como missão fundamental da UE; assinala a integração da perspetiva do género em todas as políticas comunitárias e, no N. 1, do artigo $141^{\circ}$, aplica-se o princípio da igualdade de remuneração por trabalho igual e de igual valor; e recomenda-se o uso de linguagem inclusiva.

No entanto, é o Tratado de Lisboa (2007) que consubstancia e reafirma o princípio da igualdade entre homens e mulheres e inscreve-o entre os valores e objetivos da UE. Por exemplo, o seu Artigo 2‥ 2. refere que a UE é uma "sociedade caracterizada pelo pluralismo, não discriminação, tolerância, justiça, solidariedade e a igualdade entre homens e mulheres". E no Artigo 3‥3 estabelece que a União "combate a exclusão social e as discriminações, e promove a justiça e a proteção social, a igualdade entre homens e mulheres, a solidariedade entre as gerações e a proteção dos direitos da criança."

Como nota Canotilho et al (2006), uma das marcas do feminismo em Portugal, na década de 1970 e 80, foi a insuficiência teórica e, por isso, o debate sobre o défice na igualdade de direitos entre homens e mulheres e a especificidade da situação das mulheres no quadro da igualdade, foi um percurso largo e longo. Neste processo, intervieram instituições nacionais e internacionais, Organizações Não Governamentais (ONGs), plataformas e partidos políticos. Sobretudo, os movimentos de mulheres dentro dos 
partidos políticos de esquerda, contribuíram para a construção de um sujeito político feminista que é construído na ação e na luta. Um impulso relevante foi a constituição de uma Rede de Mulheres, fundada por influência de Maria de Lourdes Pintassilgo e do GRAAL, com o objetivo de dar expressão às mulheres, às suas vidas e lutas como cidadãs (Canotilho et al, 2006; Martins, 2015)

Ana Vicente (1997: 8-10), considera que a Comissão da Condição Feminina atuou como vanguarda dos movimentos de mulheres em Portugal, e não como um departamento da Administração Pública. A sua linguagem é reivindicativa: “Apoiar todas as formas de consciencialização das mulheres portuguesas e a eliminação das discriminações contra elas praticadas, em ordem à sua inserção no processo de transformação da sociedade portuguesa, de acordo com os princípios consignados na Constituição."

Comissão para a Cidadania e Igualdade de Género (CIG), e todas as suas antecessoras tem sido o mecanismo oficial para a igualdade, com maior abrangência e maior longevidade. Esta instituição oficial, constituiu, o mecanismo que o Estado adotou para atuar nas questões da igualdade (Monteiro, 2011).

Nas diversas legislaturas, a participação de mulheres, como deputadas no Parlamento da República, era muito reduzida, e era grande o diferencial em cargos de decisão política. Em 1975 eram 20 as deputadas no parlamento. Num contexto político explosivo, Maria de Lourdes Pintasilgo, é indigitada, em 1979, para o cargo de PrimeiraMinistra, no V Governo Constitucional. Foi a primeira e única mulher a ocupar esta posição política. Esta situação "confere à categoria de género uma centralidade inusitada. Enfatizando o enquadramento de "novidade", os jornalistas confirmam que a política é masculina" (Martins, 2014: 139). A autora assinala, que a primeira dificuldade dos jornais foi de carácter linguístico, porque a ortografia e o vocabulário não previam o exercício de cargos políticos no feminino e, então, Maria de Lourdes Pintasilgo era sempre designada por Primeiro-Ministro (Martins, 2015). A escolha será fortemente questionada pelos média, mas, em 19 de julho foi indigitada para o cargo, e a 31 de julho apresentou, publicamente, o seu ministério, demonstrando grande eficácia e determinação.

A política era um domínio exclusivo dos homens e, todas as rotinas do trabalho político, iam no sentido de afastar as mulheres: as regras são ditadas pelos homens quer ao nível dos horários de trabalho, das relações simbólicas, horas das reuniões, mas também o padrão das competências e os estereótipos, eram definidos em função do universo masculino (Santos e Amâncio, 2012a; Santos e Amâncio, 2012b). A igualdade de género obrigava ou impunha uma mudança substancial do estatuto da mulher, onde a paridade seria alargada a toda a esfera da sociedade, vida profissional, familiar e participação política - uma verdadeira democracia paritária, expressão usada, pela primeira vez, por Regina Tavares da Silva, em 1989 no Seminário do Conselho da Europa em Estrasburgo (Tavares, 2008: 387). 
A deputada Teresa Ambrósio do Partido Socialista (PS), apresentou, em 1981, um projeto-lei para o aumento, em $20 \%$, da participação de mulheres nas Assembleias Municipais. Este projeto, não só foi reprovado, como mereceu a discordância da maioria das deputadas, à exceção de Teresa Santa Clara Gomes, que considerou a iniciativa muito positiva, para corrigir as graves desigualdades, entre homens e mulheres, em matéria de intervenção política (Tavares, 2008).

Depois desta iniciativa, o PS passou a ter liderança nas medidas de ação positiva, respetivamente em 1998, 2000 e 2006. Desde 1999 que o PS tinha já adotado um sistema de quotas interno: $25 \%$ de mulheres nas listas eleitorais e até nos órgãos nacionais.

As grandes questões sobre igualdade de género no debate parlamentar em Portugal estão patentes em três momentos: Parlamento Paritário - 1994; Lei de Quotas - 1999; Lei da Paridade - 2001. Finalmente aprovada, em 2006, a Lei da Paridade (Lei Orgânica 3/2006, 21 de Agosto) estabelecia que: "as listas para a Assembleia da República, para o Parlamento Europeu e para as autarquias locais são compostas de modo a assegurar a representação mínima de $33 \%$ de cada um dos sexos. Este foi o primeiro grande resultado da luta de mais de 30 anos pela aplicação de medidas de medidas de ação positiva no contexto político.

O "Parlamento Paritário", foi um acontecimento, com elevado valor simbólico, que tinha como objetivo trazer para a agenda mediática, a desigualdade de género na política em geral, e no Parlamento português em particular. Na qualificação dos acontecimentos mediático, este inscreve-se no género de pseudo-evento ${ }^{2}$, por ser produzido com a intenção de ser mediatizado.

Nesta altura, o Parlamento Europeu, desenvolvia esforços no sentido de sensibilizar os Parlamentos nacionais, para o enorme défice de representação das mulheres na política. O Parlamento Paritário foi uma iniciativa de três Eurodeputadas: Maria Belo (PS), Margarida Salema (Partido Social-Democrata-PSD) e Maria Santos (Partido Ecologista “Os Verdes- PEV). Para a Sala do Senado, entre 31 de janeiro e 1 de fevereiro de 1994, as deputadas, convidaram um número igual de deputados, experimentando, por dois dias, a experiência da paridade entre homens e mulheres.

Este evento trouxe a debate político e público, o número insignificante de mulheres no Parlamento (à data 23 deputadas em 230 mandatos), despertou a atenção para o facto

\footnotetext{
${ }^{2}$ Conceito desenvolvido pelo historiador norte-americano Daniel Boorstin em 1961 na sua obra The Image: A guide to pseudo-events in America (1987), para designar os acontecimentos não espontâneos, criados com a finalidade de ser alvo de atenção mediática. Não se trata simplesmente de um evento programado e agendado, mas de um que o seja segundo os critérios que interessam os media.
} 
de metade da população estar a ser excluída da atividade política e, abriu a oportunidade de levantar a questão da paridade.

A atenção mediática foi fortíssima e todos os jornais apresentaram o tema nas suas páginas, três deles trouxeram-no para primeira página (Público, Diário de Notícias e Correio da Manhã), e em todos foram produzidas inúmeras peças e fotografias. $O$ facto de tanto, o assunto, como a iniciativa, serem inéditos em Portugal, orientou os jornais para narrativas do género de coluna social, alguns com um tom cínico e irónico. Tal foi o caso do semanário Independente, o primeiro a noticiar o acontecimento, em 7 de janeiro de 1994, com o sugestivo título: “O menino dança?". Este jornal estabeleceu o enquadramento de uma iniciativa pouco séria e com um cunho de entretenimento, que será seguido por muitos jornais.

Apesar dos estereótipos que enquadraram a abordagem do assunto, a paridade foi debatida, com argumentos contra e a favor, mas, sobretudo, lançou o debate da desigualdade na representação política e alimentou a promessa de abertura para a tomada de medidas de valorização das questões da igualdade de género na legislatura seguinte (Cabrera, Flores e Martins, 2011).

Três anos mais tarde em 1997 a revisão constitucional reconhece a política de discriminação positiva. Dois anos mais tarde, em 1999, o Primeiro-Ministro António Guterres, cumprindo a promessa eleitoral, apresenta, na Assembleia da República, a Lei de Quotas. António Guterres é o primeiro líder a usar uma linguagem inclusiva, e antecipa mesmo, o que virá a ser consignado na revisão do tratado de Maastricht, a propósito da substituição de uma linguagem no masculino, designada como sexualmente neutra, por uma linguagem inclusiva.

Durante o seu mandato, são inúmeras as iniciativas, onde a questão da igualdade de oportunidades e a paridade, são debatidas. Porém, bastou um dia de debate parlamentar para a proposta das quotas ser chumbada, com os votos a favor do PS e da deputada Social Democrata Manuela Aguiar e os votos contra do PSD, Centro Democrático Social (CDS), Partido Comunista Português (PCP) e PEV. A cobertura jornalística deste acontecimento foi muito circunscrita ao dia do debate e o dia seguinte foram publicadas 10 peças a maioria das quais nas páginas interiores dos jornais o que significa pouco destaque ${ }^{3}$.

A questão da Paridade regressa ao Parlamento em 2001, mas o debate foi ainda mais marginal, tal como a cobertura jornalística. Por exemplo o Público de 29 de março de 2001, opta por seis textos encimados por uma fotografia de rosto, de cada uma das seis deputadas com a respetiva opinião (Cabrera, Flores, Mata, 2012).

\footnotetext{
${ }^{3}$ Os jornais considerados neste estudo foram o Diário de Notícias, Público, e Expresso e Independente
} 
Estes debates, e as tentativas frustradas de aprovação de medidas de discriminação positiva, são indicadores para o problema de desequilíbrio, que a ausência das mulheres na política, representava. Esta foi uma situação que alertou a opinião pública para a situação das mulheres, e para o impacto negativo, que esta realidade tinha na qualidade da democracia: uma democracia fragilizada que excluía metade da sua população.

No tempo em que o líder socialista José Sócrates, era Primeiro-Ministro, foi aprovada a Lei Orgânica № 3/2006 de 21 de agosto. Esta, estabelece que as listas para a Assembleia da República, para o Parlamento Europeu e para as Autarquias Locais, deviam ser compostas de modo a assegurar uma representação mínima de 33\% de cada um dos sexos. Além do mais, previa-se também um sistema de fecho éclair que obrigava cada partido, a não colocar, sucessivamente, mais de duas pessoas do mesmo sexo, nas listas e, portanto, em cada 3, uma deveria ser mulher.

A sociedade portuguesa tinha mudado, bem como os meios de comunicação social que acolhem favoravelmente esta lei, quer através da cobertura dos debates parlamentares, quer através de textos de opinião favoráveis às medidas de discriminação positiva. Havia um certo consenso quanto à questão da paridade em si, mas as divergências eram justamente quanto à existência de uma lei. Os partidos de direita consideravam que a questão do mérito devia ter a primazia, pois a paridade não se devia impor por decreto. Neste sentido, o líder do grupo parlamentar do CDS, Nuno Melo, afirmava que o PS pretende passar "um atestado de menoridade à capacidade das mulheres, quotas administrativas podem obrigar a preterir pessoas com maior vontade e capacidade" (Diário de Notícias, 9 de março de 2006).

O debate parlamentar foi aceso. Enquanto Sócrates afirmava "A Constituição manda que haja esta lei, não diz que devemos dar tempo ao tempo... Não acredito que o problema da representação das mulheres, e sei-o por experiência própria, se nos estatutos do PS, não estivesse preto no branco que um terço das listas deveria ser composta por mulheres, não teríamos as deputadas que temos hoje" (Diário de Notícias, 9 de março de 2006). Em contrapartida o PCP somou os seus votos à direita (PSD, CDS) para chumbar a lei. A Deputada comunista Odete Santos diria mesmo: "Esta flor com espinhos da paridade serve apenas para mascarar os verdadeiros objectivos do PS de distorcer a representação proporcional" (Diário de Notícias, 9 de março de 2006).

Os fatores que explicam a desigualdade de género e a resistência à aplicação de medidas ação positiva, são de natureza ideológica e estão relacionados com as organizações partidárias, "aliadas à persistência de uma visão social que considera que a esfera privada, é um mundo feminino e que a política, é um mundo masculino, tanto em termos das competências que exige, como da sua organização interna" (Santos e Amâncio, 2012: 55). Esta ideologia que perdura, é um poderoso instrumento de controlo social que impede a mudança nas relações de género. (Baum e Espírito-Santo, 2012). 
Ainda assim, os partidos de direita acabaram por incorporara a decisão e, na verdade, tanto a participação feminina, como a tomada de decisão desenvolveram-se muito no PSD (Jiménez, 2009).

Quadro 1 - Percentagem de Deputadas no Parlamento Nacional entre 2002 e 2019

\begin{tabular}{ccccccccc|}
\hline 1991 & 1995 & 1999 & 2002 & 2005 & 2009 & 2011 & 2015 & 2019 \\
\hline $\mathbf{8 , 7 \%}$ & $12,2 \%$ & 17,4 & $19,6 \%$ & $21,3 \%$ & $27,4 \%$ & $26,5 \%$ & $33,0 \%$ & $38,7 \%$ \\
\hline
\end{tabular}

Fonte: Pordata

Como se observa no Quadro1 o peso da presença das mulheres no Parlamento português passou de um número insignificante de 5,7\% em 1976, as primeiras eleições livres para a Assembleia Constituinte, e foi evoluindo muito lentamente, notando-se o crescimento da percentagem de mulheres no Parlamento a partir dos anos 90, quando as questões da igualdade passaram a estar mais na ordem do dia. Nota-se que a Lei da Paridade aprovada em 2006, teve efeitos logo nas eleições de 2009, e, em 2015, chegouse à representação de 33,0\%. As eleições de 2019 são já sob o efeito da nova Lei Orgânica n. 1/2019, que alarga a representação mínima de 40 \% de cada um dos sexos, arredondada, sempre que necessário, para a unidade mais próxima e, por isso, passámos de 76 deputadas em 2015 para 86 em 2019.

Como notam Santos e Amâncio (2012a/b), os resultados eleitorais revelaram que os partidos políticos cumpriram a lei e essa situação teve efeitos positivos no aumento da representação das mulheres na Assembleia da República e no Parlamento Europeu. Não obstante, ao nível autárquico, verifica-se uma enorme resistência, patrocinada por uma ideologia política ainda muito patriarcal.

Os debates sobre a Lei da Paridade foram fundamentais para que a questão da igualdade de género se disseminasse e difundisse, e, assim, contribuísse para a mobilização das mulheres. $O$ debate foi também ampliado pelos media e favoreceu uma opinião pública mais favorável à participação das mulheres na política. A Lei da Paridade promoveu e consolidou a tendência para o aumento da participação política feminina de tal forma que a lei orgânica Lei Orgânica N.ㅇ 1/2019 de 29 de março, contemplou já, uma representação mínima de $40 \%$ de cada um dos sexos. Ainda assim, é imprescindível chegar ao patamar da igualdade (50\%), lutar pela mudança da situação nas eleições autárquicas, promovendo mais a participação feminina, e combater igualmente todos os obstáculos, como o glass ceilings, que impedem as mulheres de ascender aos lugares de liderança e de decisão.

Portugal foi pródigo na realização de leis que eliminassem todas as formas de discriminação das mulheres e que alavancassem as questões de igualdade de género. Contudo, as novas tendências jurídico-constitucionais, imposta a partir do Parlamento 
ou do Governo, não tiveram de imediato repercussão na sociedade. Não tem sido fácil reverter as práticas, os procedimentos e as atitudes propostas pelos novos quadros legais (Martins, 2015).

Os feitos desta lei estão ainda longe de se concretizarem em toda a extensão social e política. O título do jornal Público é bastante ilustrativo da alteração da situação em Portugal "Portugal teve 35 ministras em democracia. Hoje, há 91 mulheres no Parlamento" (Liliana Borges, Público, 8 de março de 2020). Neste artigo sublinha-se também que o Governo tem uma percentagem de $42 \%$ de mulheres o que coloca Portugal acima da média da UE $(30,2 \%)$, segundo os dados do Eurostat. Por isso, o Instituto Europeu para a Igualdade de Género (EIGE Report, 2019: 32), assinala que as quotas trouxeram mais mulheres para os parlamentos nacionais, mas o progresso permanece lento e não pode ser dado como garantido."

\section{A luta pela Interrupção Voluntária da Gravidez (IVG)}

A despenalização do aborto, assunto incontornável dos direitos das mulheres, foi um tema particularmente polémico, que polarizou a vida política portuguesa ao longo de mais de 30 anos. 0 debate em torno desta questão, foi duro e por vezes, muito exaltado, e repleto de avanços, recuos, embaraços e hesitações. Reuniu um vasto número de ONGs, de movimentos e plataformas, que exerceram uma enorme pressão sobre os políticos e sobre os meios de comunicação social, esgrimindo argumentos a favor e contra.

A Constituição Portuguese de 1976, considerada, na altura, uma das mais progressistas do mundo, de entre os diversos direitos estatuídos, não mencionava o direito ao aborto. Este direito viria a ser consignado em 2007, fruto de lutas e reivindicações de organizações feministas e de mulheres que trouxeram para a arena pública o tema dos direitos sexuais (Duarte e Barradas, 2009)

Os debates sobre a IVG são paralelos à importância e protagonismo, que as mulheres vão ganhando na Assembleia da República, no Parlamento Europeu e nos lugares de liderança.

No entanto, o protagonismo das mulheres evidenciou-se fortemente nos movimentos, nas plataformas e ONGs. Já em 1974, o Movimento de Libertação das Mulheres (MLM), apresentava um conjunto de reivindicações que deviam ser integradas na Constituição de 1976. Tratava-se de assuntos como a igualdade de direitos dos dois sexos, revisão do código civil e do trabalho, salário igual, acesso às profissões em situação de igualdade 
com os homens e reformas na assistência médica. Também reivindicavam, claramente, o direito à contraceção e ao aborto e reclamavam-no enquanto direito da mulher ao seu corpo e à escolha livre. (Tavares, 2008; Almeida 2006; Monteiro, 2012)

Em 1975, Maria Teresa Horta, Célia Metrass e Helena Sá Medeiros, ativistas do MLM, publicaram um livro sobre o aborto: "Aborto o direito ao nosso Corpo". Nele defendiam que o aborto não era nem uma questão moral, nem religiosa, mas sim um problema social e político, onde a legislação devia ser feita, em simultâneo, com uma campanha de educação e planeamento familiar.

Em setembro de 1976, é constituída a União de Mulheres Alternativa e Resposta (UMAR) e, em 1977, tomaram a primeira posição pública pela legalização do aborto (Tavares, 2008). No final da década, os diversos movimentos feministas constituem a primeira plataforma comum: a Campanha Nacional pelo Aborto e Contracepção (CNAC). Esta plataforma integrava várias organizações como a UMAR, Movimento de Libertação das Mulheres (MLM), Informação e Documentação sobre Mulheres (IDM), Grupo Autónomo de Mulheres do Porto (GAMP), Grupo de Mulheres da Associação Académica de Coimbra (AAC), cujos objetivos eram a promoção do debate sobre o aborto, a despenalização e a legalização, bem como a exigência do funcionamento dos centros de planeamento familiar.

"Nome de Mulher" foi um programa televisivo, quinzenal, emitido pela RTP, entre 1974 e 1976, da autoria de Antónia de Sousa e Maria Antónia Palla e Cinequipa. Foram feitas 46 reportagens, de cinquenta minutos cada uma. O conjunto dos documentários, inventariava e debatia, os problemas das mulheres e as suas lutas no período revolucionário. Contudo, este programa televisivo viria a colocar o assunto do aborto e contraceção na praça pública, questionando a prática do aborto, e alertando para o profundo desconhecimento das mulheres portuguesas sobre os métodos contracetivos. Foram duas as reportagens sobre este tema, emitidas a 4 de Fevereiro de $1976^{4}$, com apresentação de Maria Antónia Palla, e sob o título "O aborto não é um crime".

Os protestos em relação à transmissão desta reportagem foram intensos, de tal forma que o programa "Nome de Mulher" foi suspenso e Maria Antónia Palla foi acusada de ofensa ao pudor e incitamento ao crime (Carneiro, 2017). Em Tribunal, foi defendida pela advogada Lia Viegas, e, finalmente, foi absolvida em junho de 1979.

Este julgamento foi acompanhado de várias campanhas de solidariedade, manifestações e movimentações, entre elas a da Federação Internacional de Jornalistas, que enviou ao

4 "Nome Mulher" "O aborto não é um crime". Antónia de Sousa, Maria Antónia Palla e Cinequipa. Parte I: https://arquivos.rtp.pt/conteudos/o-aborto-nao-e-um-crime-parte-i/ (consultou o 10-5-2021). Parte II: https://arquivos.rtp.pt/conteudos/o-aborto-nao-e-um-crime-parte-ii/ (consultou o 9-5-2021) 
Presidente da República e ao Presidente da Assembleia da República, telegramas onde exigiam que se respeitasse a liberdade de expressão.

Em datas próximas, e no mesmo tribunal, ocorria um outro julgamento da jovem, Conceição Massano, acusada de prática de aborto, por uma denúncia anónima, e que veio a ser absolvida por falta de provas. As manifestações de solidariedade com este caso foram muito expressivas e o assunto teve uma grande atenção mediática. A RTP no Noticiário Nacional de 29 de outubro de 1979 reportava assim as manifestações:

Manifestantes a favor da absolvição da jovem com cartaz "Nós também abortámos" e "Contraceção para não abortar! Direito ao aborto" e gritos de ordem "O crime está lei, os criminosos são vocês"5.

Estes dois casos foram acompanhados e apoiados pelos Movimentos e plataformas de mulheres, que procuravam alavancar a luta pela legalização do aborto, através da Campanha Nacional para a Contraceção e Aborto (CNAC). Promoveram manifestações, encontros, debates, e publicaram nos jornais artigos de opinião. Estes acontecimentos, alimentaram as condições, para que a despenalização do aborto entrasse na agenda mediática, na agenda pública e na agenda política (Soares, 2016).

Em 1980, o deputado Mário Tomé, da UDP apresentou, pela primeira vez o projeto-lei n. - 500/l, segundo o qual a mulher podia solicitar o aborto até às 12 semanas de gestação. Contudo este projeto não chegou, sequer, a ser debatido no Parlamento.

Dois anos mais tarde, em 1982, o PCP apresentou, no parlamento, três projetos de lei sobre a maternidade, planeamento familiar e despenalização do aborto. O debate marcado para 11 novembro 1982, ficou a cargo da argumentação da deputada Zita Seabra. Entretanto, desenvolveram-se movimentações populares, dos partidos políticos e de outras organizações que apoiavam a iniciativa parlamentar. Diversas mulheres escreveram nos jornais sobre o assunto.

Por sua vez, a Igreja Católica, fez sair um comunicado onde condenava qualquer medida legislativa que autorizasse o aborto. O Parlamento Português estava profundamente divido. As bancadas da Assembleia encheram-se de mulheres vestindo camisolas onde se lia - "Nós Abortámos". Porém, o projeto foi recusado com 127 votos contra e 105 a favor. A este propósito, Manuela Tavares afirmou em entrevista: “Aliás, a primeira manifestação nas galerias do parlamento foi nossa UMAR), em 1982, quando foi chumbado o projeto do PCP e levámos t-shirts a dizer "nós abortámos"6.

\footnotetext{
${ }^{5}$ https://arquivos.rtp.pt/conteudos/julgamento-de-conceicao-massano-dos-santos/

${ }^{6}$ Reis, Marta F. (10 de fevereiro de 2017), "Manuela Tavares sobre despenalização do aborto: "Para nós, Guterres ficou para sempre marcado", SOL. Disponível em https://sol.sapo.pt/artigo/548260/manuelatavares-sobre-despenalizacao-do-aborto-para-nos-guterres-ficou-para-sempre-marcado-
} 
Por proposta de Maria Belo, no Congresso do PS, em 1983, foi decidido fazer um projeto sobre despenalização do aborto. O Projeto lei do PS foi debatido em 26 de janeiro de 1984. A lei foi aprovada numa sessão parlamentar que durou 23 horas e ficou marcada pela disciplina de voto: lei 6/84 de 11 de maio, (aprovada com 132 votos a favor), subordinada ao seu próprio título: "Exclusão de ilicitude em alguns casos de interrupção voluntária da gravidez". Na verdade, a Lei 6/84 possibilitou, pela primeira vez, uma alteração à lei do aborto, integrada no Código Penal, desde 1886. Porém, a definição dos casos de exclusão de ilicitude, privavam as mulheres da sua capacidade de decisão. Estatuía que o aborto, só se podia verificar, em caso de perigo da vida da mãe, grave doença ou malformação do feto, situações que deviam ser verificadas e atestadas por um médico. Por isso, a UMAR alertou para o facto de que "Lei do PS mantém o aborto clandestino" (Tavares, 2008). Neste mesmo ano foram também aprovados os projetos de lei do PCP sobre "Maternidade e Paternidade" e sobre "Planeamento Familiar e Educação Sexual", este último esteve 15 anos à espera de ser regulamentado. (Tavares, 2008).

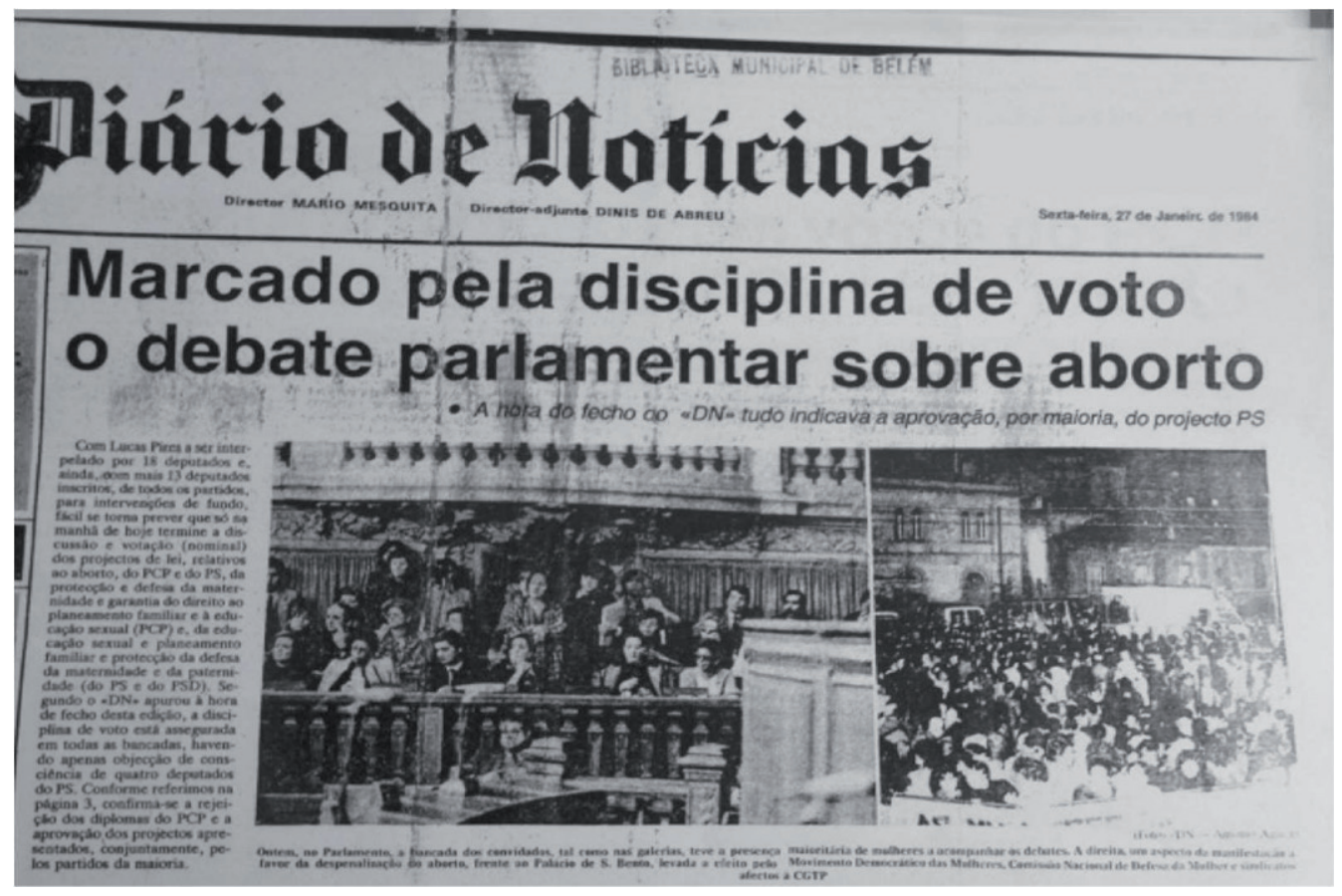

As fotografias, escolhidas pelo Diário de Notícias, mostram, à esquerda, as galerias da Assembleia da República, onde as mulheres envergavam camisolas "Nós abortámos"; à direita manifestações em frente da Assembleia da República. Diário de Notícias, 27 de janeiro de 1984, 1a página

O contexto político e económico do país influenciou este debate e o seu resultado. Tinha-se formado o Bloco Central, uma coligação entre o PS e o PSD. Este acordo devia ser mantido, já que a revisão Constitucional, que se faria nesse ano, tinha como objetivo, retirar do texto constitucional os aspetos mais radicais que vinham, ainda, de 1976. Não convinha, por isso, que se viesse a criar uma fratura na coligação. Além do mais, o Governo debatia-se com uma crise económica que conduziu à intervenção do FMI. Cumulativamente preparava-se a adesão à Comunidade Económica Europeia (CEE), 
assinada em 12 de Junho de 1985. Por isso, a questão do aborto criava um enorme desconforto no Parlamento e no Governo e podia fazer perigar a coligação. $O$ aborto clandestino continuou a ser praticado com graves riscos para a saúde das mulheres, era um problema de saúde pública (Abranches e Ferreira, 1986; Tavares, 2007; Alves et al, 2009).

A este propósito Duarte, Barradas (2009: 104) assinalam que:

Ao criminalizar o aborto, o quadro legislativo português afirmou o primado da maternidade enquanto função natural das mulheres e negou-lhes o direito à escolha e à autodeterminação sexual, remetendo-as para a clandestinidade e mantendo-as sob a espada da justiça.

A partir de 1987 até 1995 a liderança política é exercida por um Governo de centro direita, uma coligação entre o PSD e o CDS. Verificou-se, então, um endurecimento das posições em relação ao aborto. Foi nesta altura que o Ministro da Defesa, Paulo Portas, proibiu a entrada do barco da Women on Waves em águas portuguesas, tendo enviado ao seu encontro, várias corvetas da marinha, para impedir as mulheres, que pretendiam interromper a gravidez, de se aproximarem do barco.

Esta situação inflamou ainda mais o debate e alimentou protestos dos diversos movimentos de cidadania. Os grupos e plataformas de mulheres insistiram na luta pela despenalização do aborto, e desenvolveram ações que colocaram na agenda mediática a questão da igualdade de género. Podemos, assim, considerar que, durante este período, o movimento pela despenalização e pela paridade, amadureceram (Cabrera, et al 2012, 2016)

Na Associação de Planeamento Familiar, surgiu em 1990, o grupo de trabalho, Movimento de Opinião pela Despenalização do Aborto em Portugal (MODAP), que desenvolveu diversas iniciativas de sensibilização. $O$ assunto regressará ao parlamento por iniciativa do PCP em 1996 - um projeto-lei sobre a despenalização do aborto a pedido da mulher. Quase simultaneamente, Sérgio Sousa Pinto, da Juventude Socialista (JS), apresentou um projeto de despenalização a pedido da mulher e, Strecht Monteiro, do PS, avançou, também, com uma iniciativa, que integrava os motivos da lei de 1984, embora prevendo o alargamento dos prazos.

O debate voltou a ganhar intensidade, e todos os movimentos favoráveis à aprovação da lei se mobilizaram promovendo grande visibilidade no espaço público e mediático. A Igreja Católica, foi especialmente ativa no movimento pelo não, e, procurou influência juntos dos seus acólitos que, nas diversas instituições, pretenderam influenciar, de modo a neutralizar o assunto. Foi de facto o que aconteceu na Comissão da Condição Feminina que, sobre este assunto manteve o silêncio. Na altura, também o PrimeiroMinistro António Guterres, católico praticante, afirmou o seu posicionamento contra a aprovação da lei. No seio da Igreja Católica, surgiram outros movimentos que, de uma 
forma ativa, se opunham a que a lei fosse aprovada. São disso exemplo o movimento "Juntos pela Vida" que lançaram a campanha "Não Mates o Zezinho".

A 4 de fevereiro de 1998, o projeto de lei n. 451/VII, sobre exclusão da ilicitude de casos de interrupção voluntária da gravidez, apresentado pelo JS, foi aprovado com 116 votos a favor, 107 contra e 3 abstenções.

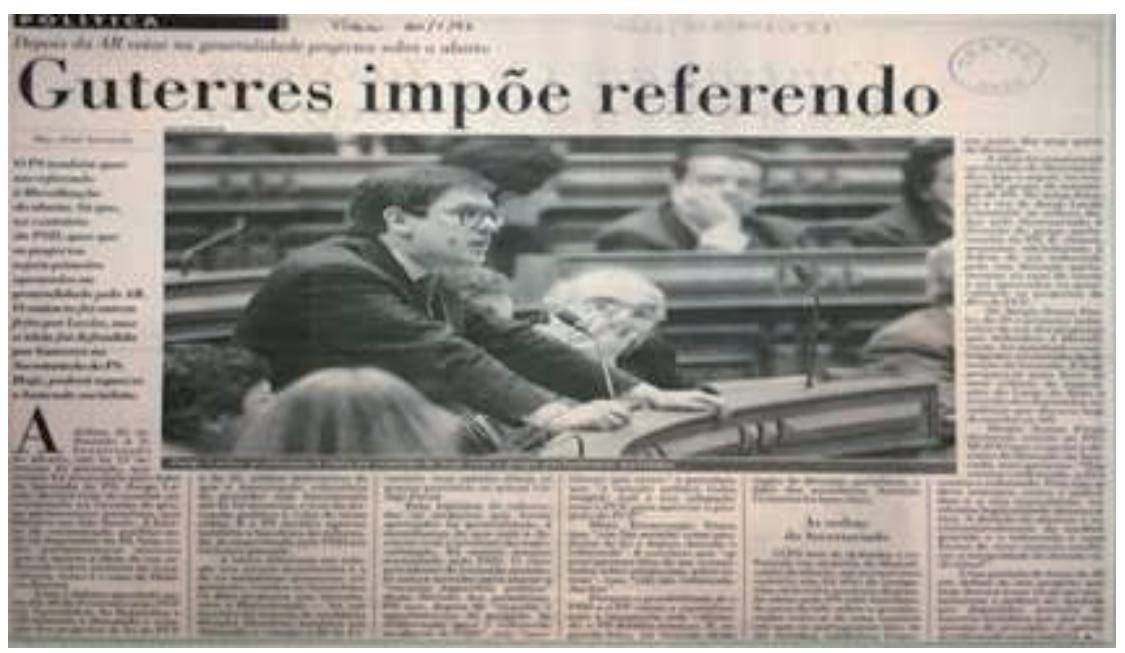

Jorge Lacão (em primeiro plano), líder do grupo parlamentar do PS, tinha uma difícil situação a gerir tensão entre a vontade da maioria do grupo parlamentar do PS, e a vontade do Primeiro-Ministro António Guterres. Fonte: Casa comum, Fundo UMAR, Pasta 10092.006.002.031. Público, 30/1/1997

Não obstante, António Guterres, Primeiro-Ministro Socialista, católico e abertamente contra a lei, não se conformou, e chegou a um entendimento com Marcelo Rebelo de Sousa, na altura líder do PSD. Ficou então acordado a realização de um referendo, marcado para 28 de junho de 1998 . O referendo foi recusado (60\% abstenções; $49 \%$ de SIM; 51\% - NÃO) e, mais uma vez o problema foi adiado.

Numa entrevista ao jornal SOL Manuela Tavares, militante da UMAR e ativista pelo movimento pela despenalização do aborto, declara numa entrevista:

Lembro-me que estivemos no parlamento até muito tarde [as atas referem que a votação terminou pelas 21h05], como fazíamos sempre que havia alguma discussão. Aliás, a primeira manifestação nas galerias do parlamento foi nossa, em 1982, quando foi chumbado o projeto do PCP e levámos t-shirts a dizer "nós abortámos". Mas, naquele dia, a lei tinha sido aprovada(...) "Acordámos com esse balde de água fria, surpreendidos pela comunicação social de que estava a ser preparado um acordo entre PS e PSD para que existisse o referendo7.

As consequências da vitória do "Não" no Referendo de 1998 foram dramáticas. A norma penal então existente, conduziu à realização dos primeiros julgamentos por prática de

\footnotetext{
${ }^{7}$ Reis, Marta F. (10 de fevereiro de 2017), Entrevista a Manuela Tavares, Semanário SOL.
} 
aborto em Portugal. Os julgamentos de mulheres devido a prática de aborto, na Maia (2001), Aveiro (2003), Setúbal e Lisboa (2004), romperam com as ideias, que alguns defendia, que a lei não conduziria mulheres a julgamento. Pelo contrário, aqueles julgamentos, colocaram em evidência, a criminalização de mulheres que decidiam interromper a gravidez (Tavares, 2007; Santos e Alves, 2009).

A luta contra esta situação, profundamente desajustada, já no início do novo milénio, originou um recrudescimento dos movimentos cívicos. Manifestações e ações de solidariedade, colocaram de novo o assunto na agenda mediática. Recolheram-se então mais de 120 mil assinaturas para a realização de um novo referendo. Também a campanha Fazer Ondas, foi um exemplo de participação cívica e democrática que em muito, contribuiu, entre os dois referendos $(1998,2007)$, para uma revitalização da luta pela legalização da IVG (Alves et al, 2009; Duarte e Barradas, 2009; Cabrera et al, 2012).

Finalmente, já noutra legislatura, liderada pelo socialista José Sócrates, um novo referendo é marcado para 11 de fevereiro de 2007. O resultado veio dar a vitória ao sim, originando a Lei n.․ 16/2007 de 17 de abril.

\section{Discussão e Conclusões}

Quando se instaurou a democracia em Portugal, depois do 25 de abril, verificava-se um grande défice da participação feminina na política e na tomada de decisões. A entrada para Comunidade Europeia, em 1986, veio colocar o assunto, embora de forma tímida, através da aprovação do "Programa Comunitário a Médio Prazo para a Igualdade de Oportunidades para as Mulheres (1986-1990)". As medidas de ação positiva em relação à política não eram ainda consideradas, como não era considerada a liberdade da mulher poder dispor livremente do seu corpo e da sua vontade em relação a uma gravidez.

Os anos 90, comportaram um conjunto vasto de ações internacionais, entre elas a 4a Conferência Mundial sobre a Mulher que se realizou em Pequim em 1995. As suas decisões foram transversais, englobaram o programa de ação que convergia no empoderamento da mulher e nas questões da igualdade de género que, doravante, seriam encaradas como direitos humanos fundamentais. Também os diversos tratados da UE promoveram a igualdade entre homens e mulheres. Mas, foi sobretudo o Tratado de Lisboa, que consubstanciou o princípio da igualdade em todos os domínios.

Ainda assim, os vários países da CE teriam que fazer os seus próprios caminhos, considerando os diversos entraves relativos às especificidades nacionais. Em Portugal, nos primeiros anos da democracia, a política era o domínio dos homens. Apesar de 
várias iniciativas, o imobilismo dos partidos políticos, em dar lugar às mulheres na política, em posições elegíveis, continuava a criar obstáculos. Os debates na Assembleia da República dividiam-se, entre os argumentos baseados no mérito próprio de cada mulher, e as medidas de ação positiva que contribuíam para acelerar a participação das mulheres na política.

O PS liderou as iniciativas de ação positiva ao nível interno e, desde $1999,25 \%$ das listas eleitorais e órgãos nacionais, são mulheres. Contudo falharam as duas tentativas de parlamentares: Lei de quotas - 1999 e Lei da Paridade - 2001. Finalmente, foi aprovada a Lei da Paridade (Lei Orgânica 3/2006, 21 de Agosto) que estatuía 33\% de cada sexo nas listas para a Assembleia da República, Parlamento Europeu e Autarquias Locais. A partir de 2009, a lei começou a ter efeito com aumento do número de mulheres nos parlamentos e, com a nova lei de 2019 , a quota de mulheres amentou para $40 \%$.

Mas a questão da igualdade na liderança está ainda longe de se concretizar. Há um caminho a percorrer para eliminar os obstáculos que as mulheres têm para alcançar os lugares de liderança. A luta pela paridade é, portanto, um processo em aberto, onde os meios de comunicação desempenham um lugar fundamental. No processo de luta pela paridade os meios de comunicação também se foram moldando e modificaram as suas práticas, não só na forma como enquadravam as peças sobre as mulheres, mas também na abertura de ângulos e na problematização dos assuntos. Ao dar visibilidade às mulheres na política, contribuem para naturalizar a presença feminina em todos os sectores da sociedade e, por isso, têm um efeito de multiplicador social. Na verdade, hoje temos, em Portugal, mais mulheres na política, mas também na imprensa e na televisão, nas media aumentou o número de mulheres que fazem comentário político, que foi, durante muito tempo, um feudo masculino.

Por seu turno, a luta pela despenalização do aborto foi longa e ocupou a sociedade e os media durante mais de 30 anos. Recordamos que em 1982 a proposta do PCP foi reprovada, em 1984 o assunto voltou ao parlamento e o aborto é aprovado, só em caso de risco de vida da mulher. Em 1997-98 a IVG foi aprovada no Parlamento, mas, António Guterres, Primeiro-Ministro, chegou a um entendimento com Marcelo Rebelo de Sousa e acordaram a realização de um referendo, cujo resultado foi negativo. Só 10 anos mais tarde, em 2007, se realizou um novo referendo e, desta vez, a IVG será aprovada.

Durante 27 anos estes foi um assunto que absorveu a atenção pública, embora não de forma continua. A sociedade portuguesa questionou-se sobre o aborto e todas as matérias relacionadas: a saúde materno infantil, a saúde da mulher, a educação sexual, a contraceção. Programas como "Nome de Mulher", da autoria de Antónia de Sousa e Maria Antónia Palla, a sua suspensão e proibição e o consequente julgamento de Maria Antónia Palla, alertou, logo nos em finais dos anos 70, para quão difícil ia ser o processo e a luta. 
Cada vez que o assunto subia ao Parlamento, a intensidade do debate recrudescia e um número maior de mulheres organizava-se, manifestava-se, promovia campanhas de solidariedade e sessões de esclarecimento.

Exigia-se a contraceção para não abortar, mas a engrenagem de uma sociedade patriarcal, ainda atávica, com muitos caciques no ativo e uma forte influência da igreja, condicionavam as decisões políticas.

Na verdade, vivia-se uma situação em que o quadro legislativo adotava a maternidade como função natural da mulher, privando-a do direito de escolha, negando-lhe a autodeterminação sexual, arrastando-a para o aborto clandestino e consequente intervenção dos Tribunais. Esta situação foi, por diversas ocasiões, vivida em julgamentos tumultuosos, alguns deles realizados já no princípio do milénio.

Este foi o tema que mais envolveu as mulheres, e que mais contribuiu para a sua tomada de consciência. As mulheres perceberam, que não tinham autonomia, nem liberdade, para tomar decisões sobre o seu corpo, fora da alçada dos homens, nem eram responsáveis por si mesmas. Este debate, contribuiu igualmente, para quebrar tabus sobre questões sexuais, demonstrou como os direitos da mulher eram inferiores aos dos homens, e revelou-se uma questão central no movimento feminista. Este foi um processo verdadeiramente emancipador das mulheres, porque foi o tema que mais as envolveu, e que mais contribuiu para a sua tomada de consciência.

O mundo da política é inseparável da mediação jornalística e, a afirmação da mulher na política, passa pela notoriedade que é um dos valores-notícia da seleção informativa. Por seu turno, a exposição mediática das mulheres em cargos de liderança, tem um efeito mimético na sociedade. Os meios de comunicação acompanharam os tempos e as mudanças sociais. A imprensa mobilizou-se e promoveram-se debates, proliferaram os artigos de opinião na imprensa e os debates na televisão. Não obstante, os mecanismos de transmissão dos estereótipos de género permaneceram, na maior parte das vezes, ocultos. Gallego (2004: 162-167), assinalou que os mecanismos de transmissão de estereótipos estão dispersos e são transversais a várias esferas, onde a produção jornalista está ancorada: a organização empresarial, a cultura profissional dos jornalistas, o contexto socio cultural e as idiossincrasias pessoais.

Contudo, por muito abertas, avançadas ou progressistas que sejam as leis, por muitos direitos que consignem, a autonomia política e a independência, não são simplesmente o resultado de marcos legais, mas sim de uma transformação de mentalidades, valores e comportamentos sociais. Por outro lado, as conquistas feministas estão profundamente ancoradas em sociedades democráticas, a democracia tem as suas fragilidades e as conquistas alcançadas não são definitivas. Sobrevivem ao sabor de movimentos políticos, lideranças, crises económicas ou pandémicas. Como sublinhou Simone de Beauvoir, em $O$ segundo sexo, as relações de género são relações de poder. 


\section{Referencias bibliográficas}

ABRANCHES, G., Ferreira, V. (1986) "O debate sobre o aborto e a ortopedia discursiva da sexualidade”, Análise Social, Vol. XXII (92-93), 1986-3-4 477-492

ALMEIDA, São José (28 de janeiro de 2006) “As feministas de um país oficialmente sem feminismos",

Público,

p.

https://static.publico.pt/DOCS/AsFeministasdeUmPais.pdf (acedido em 13 de março de 2021)

ALVES, M., SANTOS.A.C, BARRADAS, C, DUARTE, M. (2009). “A despenalização do aborto em Portugal - discursos, dinâmicas e acção colectiva: os referendos de $1998 \mathrm{e}$ 2007", Oficina do CES, n. 320, janeiro de 2009 (acedido em 7 de janeiro de 2020)

BALANZA, M.T.V. (2004) "La construcción del género en los medios de comunicación: la segregación del discurso informativo" en M. Teresa V. Balanza e Rosa B. García (Editoras), Mujeres y medios de comunicación, Imágenes, mensajes y discursos, Atenea: Universidad de Málaga. P. 133-149

BAPTISTA, C. (2017) "Género e jornalismo parlamentar em Portugal”, Mídia, Gênero \& Direitos Humanos. V. 6 - No 01 - Ano 2017 - ISSN | 2179-7137, P. 143-171 https://periodicos.ufpb.br/ojs2/index.php/ged/article/view/25857/18390 (acedido em 11.3.2021)

BAUVOIR, S. (1949/1999) "Le deuxième sexe: Les faits et les Mythes", Tome 1, Paris: Gallimard

Boletim da Comissão da Condição Feminina, março de 1976: 5

BOORSTIN, D. (1961/1987) The Image: A guide to pseudo-events in America. New York: Vintage

CABRERA, A. BAPTISTA, C. MARTINS, C. MATA, M. J. FLORES, T. M. (2016) Política no Feminino, Lisboa: Aletheia Editores ISBN:978-989-622-877-4.

CABRERA, A. FLORES, T.M., MATA, M.J. (2012) "O feminino como "intruso" na política: uma análise do contexto histórico e da representação fotojornalística das deputadas portuguesas no "parlamento paritário" e nas discussões da lei da paridade", Media \& Jornalismo. N. 21, Vol. 11, 77-128

CABRERA, A. MARTINS, C. FLORES, T.M. (2011) "Representações Mediáticas das deputadas portuguesas", Brazilian Journalism Reseearch. Volume7-Número1l2011, 75-93

CABRERA, A., FlORES, T. M., MARTINS, C., MATA, M. J. (2012). “Do Parlamento para os jornais: reflexos mediáticos dos debates da IVG em 20 anos de democracia 
portuguesa, en FERIN CUNHA, I., CABRERA, A., SOUSA, J.P. (Editores), Pesquisa em Media e Jornalismo. Homenagem a Nelson Traquina. Covilhã: LabCom. Capítulo VII, pp. 159-201.

CABRERA, A., MARTINS, C. (2019) "Representações jornalísticas do poder político no feminino em tempo de crise", en CABRERA, A., SANTOS, C.A., FIGUEIRAS, R.(Editoras), Media: Poder, Representação e Epistemologias, Imprensa da Universidade de Coimbra. Pp. 95-121

CANOTIlHo, A. P., TAVARES, M., MAgAlHÃES, M. J. (2006), ONG,s e Feminismos: contributo para a construção do sujeito político feminista, Ex aequo, no 13, pp 9199

CARNEIRO, M. (2017) "Mulheres de Abril: Testemunho de Maria Antónia Palla". EsquerdaNet, 30 de maio de 2017. Disponible en: https://www.esquerda.net/artigo/mulheres-de-abril-testemunho-de-mariaantonia-palla/48964

CERQUEIRA, C. (2012) Quando elas (não) são notícia: mudanças, persistências e reconfigurações na cobertura jornalística sobre o Dia Internacional da Mulher em Portugal (1975-2007), Tese de doutoramento em Ciências da Comunicação (especialidade de Psicologia da Comunicação). Universidade do Minho. http://hdl.handle.net/1822/20789 (Acedido em 11.3.2021)

DUARTE, M. e BARRADAS, C. (2009) "Entre a legalidade e a ilegalidade: representações em torno do direito ao aborto em Portugal". E-Cadernos CES, 4, 2009, P. 79-107 https://journals.openedition.org/eces/222 (Acedido em 8.1.2021)

FRANCISCO, S. CAETANO, M.J. (9 de março 2006) "PCP ao lado da direita contra lei da paridade", Diário de Notícias.

GALLEGO, J. (2004) "De las recomendaciones a los mecanismos: producción informativa y transmisión de estereotipos de género", en VERA BALANZA, M.T. e GARCÍA, R.B. (Editoras), Mujeres y medios de comunicación, Imágenes, mensajes y discursos, Atenea: Universidad de Málaga. P. 151-170

HORTA, M.T., METRASS C., MEDEIROS, H.S. (1975) Aborto o direito ao nosso Corpo, Lisboa: Editorial Futura

Instituto Europeu para a Igualdade de Género (EIGE) (2019) Report on equality between women and men in the EU, European Comission

JIMÉNEZ, A.M.R. (2009) Women and decision-making participation within rightist parties in Portugal and Spain. Análise Social, vol. XLIV (191), 2009, 235-263 
MARTINS, C. (2014) Maria de Lourdes Pintasilgo: A "Senhora Primeiro-Ministro" na cidade dos homens. Media \& Jornalismo, n.ㅇ 25, vol. 14, n. 2, 2014, P. 125-142 - (2015) Mulheres liderança política e media, Lisboa: Aletheia Editores, ISBN: 978989-622-761-6

MONTEIRO, R. (2011), “A política de quotas em Portugal: o papel dos partidos políticos e do feminismo de Estado", Revista Crítica de Ciências Sociais, n. . 92, P. 31-50 DOI: $10.4000 /$ rccs.3953

NORRIS, P, LOVENDUSKI, J. (1989) "Women candidates for Parliament: Transforming the Agenda?", British Journal of Political Science, 19:1, 106-115

NORRIS, P. INGLEHART, R. (2001) "Women and Democracy. Cultural Obstacles to Equal Representation", Journal of Democracy, 12.3, 126-140

Pordata

https://www.pordata.pt/Portugal/Mandatos+nas+eleições+para+a+Assembleia+ da+República+deputados+do+sexo+feminino+em+percentagem+do+total++por+ partido+pol\%C3\%ADtico-2261

REIS, M. F. (10 de fevereiro de 2017), "Entrevista a Manuela Tavares", Semanário SOL https://sol.sapo.pt/artigo/548260/manuela-tavares-sobre-despenalizacao-doaborto-para-nos-guterres-ficou-para-sempre-marcado-

ROSS, K. COMRIE, M. (2012). "The rules of the (leadership) game: Gender, politics and news, Journalism, 13 (8), 969-984 DOI: 10.1177/1464884911433255

SANTOS, A.C., ALVES, M. (2009) Entre referendos - contributos e representações sobre a Campanha Fazer Ondas na luta pela despenalização do aborto em Portugal, $e$ cadernos CES, 4 2009, 47-78. DOI: 10.4000/eces.216

SANTOS, M. H. e AMÂNCIO, L. (2012 a) Género e política: análise sobre as resistências nos discursos e nas práticas sociais face à Lei da Paridade», Sociologia, Problemas e Práticas [Online], 68, P.69-101 (Acedido em3 de março 2020)

-. (2012b), "Resistências à Igualdade de Género na Política", ex æquo, n. 25, 2012, pp. 45-58 (Acedido em 3 de março 2020)

SILVA, R. T. da (2010) "A situação das mulheres no mundo: que progressos no caminho da igualdade 15 anos depois da Plataforma de Acção de Pequim? Revista de Estudos Demográficos INE, 2010, p. 5 - 20 https://ine.pt/xportal/xmain?xpid=INE\&xpgid=ine_genero_estudo\&menuBOUI= $13707294 \&$ contexto $=$ pge\&ESTUDOSest_boui $=90345333 \&$ ESTUDOSmodo $=2 \&$ sel Tab=tab2\&perfil=1464373\&xlang=pt (Acedido em 12.1.2021)

SILVEIRINHA, M.J. (2006) “Representações mediáticas das mulheres", Ex aequo, n. 14 
SILVEIRINHA, M.J. PEIXINHO, A. T. (2008), "The Law of Life and The Law of Quotas", in Communication Policies and Culture in Europe, European Communication Research and Education Association, Barcelona

SOARES, M. G. (28 de dezembro de 2016), "Morreu Lia Viegas", Expresso, https://leitor.expresso.pt/pesquisa?q=Morreu+Lia+Viegas

TAVARES, M. (2007) "A longa luta das mulheres portuguesas pela legalização do aborto:"http://webcache.googleusercontent.com/search?q=cache:XCeIZRUaSaM J:umar.sc16.co.uk/images/stories/pdf/Imlegalizacaolaborto.pdf+\&cd=1\&hl=ptPT\&ct=clnk\&gl=pt\&client=safari (acedido em 7 de janeiro de 2020)

TAVARES, M. M. (2008) Feminismos em Portugal 1947-2007, Tese de doutoramento apresentada na Universidade Aberta. Doutoramento em Estudos sobre as Mulheres Especialidade em História das Mulheres e do Género. https://repositorioaberto.uab.pt/bitstream/10400.2/1346/1/Tese\%20de\%20dou toramento\%20Manuela\%20TavaresVF.pdf (Acedido em 10.1.2021)

VICENTE, A. (1997), 20 anos ao serviço da Igualdade, Presidência do Conselho de Ministros. Alto-comissário para as Questões da Igualdade e da Família, Lisboa: Comissão para a Igualdade e para os Direitos da Mulher. 